\title{
The Trade Effects of Regional Agreements and Economic Integration Processes in Europe, South America, and North America
}

\author{
Oscar David Andrés Julián López Camargo* \\ Alexander Carvaja ${ }^{* *}$
}

\begin{abstract}
This article seeks to understand the effects of trade creation and diversion in regional agreements and integration processes in Europe, South America, and North America. Through a systemic literature review, and based on the economic theory of integration, it analyzes the impact of tariff barriers on trading volume through the world, as well as the impact of barriers removals in member and non-member countries that participate in these trade agreements. As hypothesis, it can be stated that the trade effects generated by economic integration processes vary depending on the endogenous conditions of the industries in member countries, in addition to the consolidation phase of the integration processes. For this purpose, a qualitative descriptive methodology, based on an analysis of literature, is used to determine the trade creation and deviation effects of agreements in Europe (European Union), South America (MERCOSUR and CAN), and North America (NAFTA).
\end{abstract}

Keywords: International trade, economic integration, trade creation, trade deviation, trade agreements

\section{Resumen}

Este artículo busca comprender los efectos de creación y el desvío de comercio producidos por los acuerdos regionales y los procesos de integración en Europa, América del Sur y América del Norte. A través de una revisión de la literatura, y con base en la teoría económica de la integración, se analiza el impacto de las barreras arancelarias en el volumen de comercio en todo el mundo, así como el impacto de la eliminación de barreras en países miembros y no miembros que participan en estos acuerdos comerciales. Como hipótesis, se puede plantear que los efectos comerciales que generan los procesos de integración económica varían en función de las condiciones endógenas de las industrias en los países miembros, además de la fase de consolidación del proceso de integración. Para ello, se utiliza una metodología descriptiva cualitativa, basada en un análisis de la literatura, para determinar los efectos de desviación y creación de comercio de acuerdos en Europa (Unión Europea), América del Sur (MERCOSUR y CAN) y América del Norte (TLCAN).

Palabras clave: Comercio internacional, integración económica, creación de comercio, desviación de comercio, acuerdos comerciales.

JEL classification: F1, F15.

\footnotetext{
* Lecturer and researcher from Saint Thomas University, Colombia. Master in Foreign Affairs. Email: oscar.lopezc@usantoto.edu.co. Received: July 14th, 2020; modifications: October 15th , 2020; accepted: December 30th, 2020.

** Lecturer and researcher from Saint Thomas University, Colombia. Master in Applied Statistics. Email: Alexander.carvajal@usantoto.edu.co
} 
Oscar David Andrés Julián López Camargo \& Alexander Carvajal

The Trade Effects of Regional Agreements and Economic Integration Processes in Europe, South America, and North America

\section{Introduction}

Both, economic integration processes ${ }^{1}$ and trade agreements, are characterized primarily by the political benefits they generate in member countries; though, they also generate economic costs. In contrast, unilateral trade liberalization possesses lower economic costs but do not generate political benefits. This difference helps explain why the majority of countries prefer to opt for economic integration to achieve specialization and efficiency in the allocation of resources, thus achieving welfare gains in member countries. However, all economic integration processes can generate two outcomes regarding trade flows at the international level. One the one hand, trade diversion, which is understood as a reduction in international trade flows when a country replaces imports from a third -non-member- party with imports from a member country at a higher price, reducing international trading volume. On the other hand, trade creation understood as the replacement of higher cost imports from a third country with imports from a member country at a lower cost, generating an increase in global trade flows. Economic integration processes must constantly face this dichotomy, which directly impacts the welfare of the societies involved in integration processes. Moreover, there is no clear explanation about the success on some regional agreements in terms of trade flows and how others regional agreements decrease trade flows.

Hence, is fundamental to approach the most significant regional agreements in Europe, South America, and North America to achieve a better comprehension on the conditions and the influence of the stages of each economic integration processes, that affects trade flows in these regional agreements. Thus, this papers looks into the following research question: What are the trade effects generated by economic integration processes in Europe, South America, and North America? As hypothesis, it can be stated that the trade effects generated by economic integration processes vary depending on the endogenous conditions of the industries in member countries. This is in addition to the consolidation phase experienced by member countries in integration processes given that trade creation effects can exceed those of trade diversion, increasing international trading volume. Additionally, the nature of the agreements, together with the commitment of member countries, can alter the trade effects resulting from regional agreements.

The general objective of this article is to review the trade effects of economic integration processes in Europe, South America, and North America. To do so, it is necessary to analyze not only the nature of preferential trade agreements and regional agreements, but also the influence of the endogenous conditions in each trade area. Additionally, the trade effects of tariff and non-tariff barriers in regional agreements must be studied. Finally, the effects of trade creation and diversion in customs unions and free trade agreements must also be analyzed.

\footnotetext{
${ }^{1}$ Economic integration may be understood as the process of removing progressively all the trade discriminations (tariff and non-tariff barriers) within an area among member countries. However, for this article, it is necessary to add that an integration economic process should follow linear stages of economic association model, from a free trade area to a full economic integration.
} 
To demonstrate the hypothesis of this article, a qualitative descriptive methodology is used in which the trade effects of preferential trade agreements (PTAs) ${ }^{1}$ and regional trade agreements (RTAs) ${ }^{2}$ are analyzed. This analysis is conducted through a literature review comprising works that studied the variables affecting trade creation and diversion, followed by the effects generated by tariff and non-tariff barriers in regional agreements. Papers were selected according to their characteristics, including those that measured the trade effects in agreements in Europe, South America, and North America for the period covering between 1950 and 2010. This period of time was selected as it was fundamental in the debate between unilateral tariff reduction vs the regional integration. To respond to the geographical scope of the paper, the trade effects of the European Union (EU), the Southern Common Market (MERCOSUR) and the Andean Community (CAN) are analyzed based on the phases of integration together with the endogenous conditions of member countries. Meanwhile, for the case of the North American Free Trade Agreement (NAFTA), the issue of whether the trade creation effects among member countries compensate for reduced trade between member countries and the rest of the world is reviewed. Hence, this paper attempts to review the most significant research about trade effects on these regional agreements.

The results that support the hypothesis are grouped into four reasons. First, it is established that regional preferential agreements are zones of exclusion with regard to third parties where the conditions of the member countries have a greater effect on global trading volume than the agreements themselves. Second, from the analysis of the nature of free trade areas and customs unions, it is established that the former generates trade diversion in its initial years, but this is later corrected through the elimination of tariff barriers designed to protect the industries that established them, while for customs unions it is identified that the trade creation effects exceed those of trade diversion in the long term. Third, it is argued that the EU as an economic bloc increased global trading volume in the long term, while regional agreements studied in South America (MERCOSUR and CAN) generated trade diversion. Fourth, it is argued that for the case of the NAFTA, trading volume between member countries was successfully increased, overcoming the reduction in trading volume of those countries with the rest of the world, and hence that the agreement generated trade.

This article is divided in four sections. First, it exposes the different kinds of regional agreements and their impact on international trade, plus the influence of the inner conditions of the members on the trade flows outcome. In the second section, it discusses the role of tariff and non-tariff barriers on trade effects, alongside the repercussion of the stage during the economic integration process on trade diversion and trade creation. The third section establishes the theoretical framework about the impact of the trade effects on wealth, and the repercussion of the regional trade agreements on the transition from trade diversion to trade creation. The fourth section, based on the literature, analyzes the trade effects of the EU, MERCOSUR, CAN and NAFTA according to the stages of the economic integration process and the volume of international trade. Finally, some concluding remarks are presented.

\footnotetext{
1 According to the World Trade Organization (WTO), PTAs are unilateral trade preferences that introduce a standardized system of preferences schemes (under which developed countries privileges preferential tariffs to imports from developing countries), along with other non-reciprocal preferential schemes.

${ }^{2}$ RTAs can be understood as a treaty between two or more states to allow free movement of goods and services within a geographical area.
} 
Oscar David Andrés Julián López Camargo \& Alexander Carvajal

The Trade Effects of Regional Agreements and Economic Integration Processes in Europe, South America, and North America

\section{Regional agreements and trade flows}

Regional integration processes generate impacts not only in member countries but also in third parties, especially if they are developing countries, which raises questions concerning the costs and benefits of these processes in international trade (Koko et al., 2005). Some critics view regional integration processes as protectionist blocs that reduce multilateral trade (Yeats et al., 1997). Others argue that the establishment of regional blocs increase free trade (Koko et al., 2005). In the presence of trade diversion bilateral agreements tend to reduce multilateral negotiations given that their increase or reduction in tariffs have a more significant impact than any other measure in the World Trade Organization (WTO) (Robertson and Stevadeordal, 2009). Hence, when there is a reduction in tariffs as a result of a bilateral agreement, international trade increases because the bilateral agreement tends to increase the difference between average tariffs and the remaining tariffs. In this sense, bilateral agreements are as effective for trade divergence as the remaining tariffs are at blocking trade (Robertson and Stevadeordal, 2009). For this reason, trade agreements inevitably affect international trade, regardless of whether they are integration processes or bilateral agreements, as changes in tariffs have a significant impact on trade diversion and trade creation.

Tariffs in multilateral agreements tend to reduce trade flows, while tariffs in preferential agreements tend to generate trade diversion (Haveman et al., 2003). In this sense, both multilateral and preferential agreements end up being exclusive towards third-party countries, and they affect trading volume both for member countries and third parties. Thus, with higher tariff barriers in multilateral agreements, trade is redirected towards exporters with greater abilities to reduce the fixed costs associated with trade, isolating from the benefits of trade those countries that are unable to reduce these costs (Haveman et al., 2003). These multilateral agreements end up harming developing countries due to their inability to reduce their fixed costs.

Some studies regarding preferential agreements are carried out using the model proposed by Viner (1950), which predicts that the majority of preferential trade agreements will generate diversion, although depending on the size of the country, it will prevail trade creation or diversion (Bhagwati and Panagariya, 1996; Prehn et al., 2012). Studies using Viner's model initially focused on the intensive margin of trade, but now also on includes the extensive margin of trade. Empirical evidence demonstrates that a preferential agreement not only increases sales by current exporters but also induces in new businesses the ability to export, depending directly on the heterogeneity and business structure of the country (Prehn et al., 2012). In addition, it has been found that both the imposition of non-tariff barriers and their reduction allows for an increase in the value of trade in products for which there is low demand (inelastic imports). An increase in prices has a greater impact than a reduction in quantity (Haveman et al., 1998). However, the analysis of the heterogeneous business structure of member and non-member countries in preferential agreements is determinant for establishing trade diversion given that, if the level of heterogeneity of the firm is greater in the country with preferential status compared to a non-member country, the price increases, which moves trade (Prehn et al., 2012). Additionally, non-tariff barriers tend to have a smaller distortion effect in those industries characterized by differentiated products (Prehn et al., 2012). Thus, it is possible to understand the complexity of calculating preferential agreements trade diversion or creation, as there are many variables that can interfere with the increase or decrease in international trading volume. 
One of the main concerns during the negotiations of the General Agreement on Tariffs and Trade (GATT) was the search for the reduction in tariff and non-tariff barriers in international trade given that trade diversion is more sensitive to tariff reductions that result from preferential trade, than to the reduction in tariff barriers in a multilateral agreement (Haveman et al., 1998). Likewise, Muhammad and Yucer (2009) using a gravity model established that trade flows based on the sizes of economies and the distance between two units are significant in trade diversion or creation. Thus, a home bias exists for many industries, where the elasticity of substitution is greater among foreign goods than among domestic production and imports (Haveman et al., 1998).

In this way, impacts are reflected in sudden trade flow changes which can have a financial impact on small countries due to factors exogenous to the agreement (Muhammad and Yucer, 2009). When average tariffs rise, in multilateral agreements, trade is reduced disproportionately and falls on small exporters. Consequently, some developing countries opt for the strategy of exporting a variety of products from small industries instead of diversifying the spectrum of products in their exports (Haveman et al., 1998). If the members of an organization of this type do not prepare their trade policies correctly, they will end up obstructing trade, which would generate diversion (Saryan, 1998). The endogenous conditions in countries that sign preferential agreements are more significant in trade diversion or creation than the agreement itself, specifically regarding the issue of non-tariff barriers.

Regional agreements generate trade diversion effects; hence, its proliferation implies a reduction in multilateralism (Pandey, 2006). Even so, with certain partners, trade liberalization generates positive effects. In fact, high-cost domestic products can be substituted for lower-cost products from member countries. Third countries must face higher tariff barriers than those of member countries, distorting the prices of their products. Consequently, consumers within the agreement will have a preference for products from member countries even if these are not the most competitive (Sorgho, 2016). Discrimination against third parties is a central problem in preferential agreements, although it is true that the selective abolition of tariffs can eliminate protectionism and distortions among the parties to an agreement to create effects that generate trade and growth (Mildner and Schmucker, 2013). It is also true that trade diversion occurs when the dismantling of trade barriers gives the partner country's goods and services a competitive advantage, even if a third-party country can produce the goods and services more efficiently (Mildner and Schmucker, 2013). It is thus clear that a single regional agreement can generate both trade creation and diversion effects. It is generally expected that the trade creation effects are stronger than the diversion effects.

\section{Tariff and non-tariff barriers in trade effects in regional agreements}

The last decade has witnessed a significant increase in RTAs. Hence, promoting the analysis that relates the number of RTAs to the impact in terms of trade diversion or creation around the world, given that these agreements have generated what is known as the "spaghetti bowl" effect. ${ }^{3}$ Moreover, this proliferation has weakened international negotiations. Trade diversion occurs, but there are also fluctuations in investment and little clarity regarding the reasons for which a country enters or remains in an agreement, which directly affects their success and permanence (Bauman, 1993). However, the

\footnotetext{
3 The "spaghetti bowl" is a metaphor used to illustrate the multiple alliances of regional trade agreements that must coexist with innumerable applicable tariff types, as well as a multiplicity of rules of origin (Sorgho, 2016).
} 
Oscar David Andrés Julián López Camargo \& Alexander Carvajal

The Trade Effects of Regional Agreements and Economic Integration Processes in Europe, South America, and North America

formation of RTAs between countries has evolved given that RTAs have long focused on members that were geographically close to each other, for example the European Union (EU), NAFTA, Economic Community of West African States (ECOWAS), and the Association of Southeast Nations (ASEAN) (Sorgho, 2016). Thus, in the Western Hemisphere, the volume of trade is shrinking in the case of MERCOSUR and NAFTA, where there is significant trade diversion (Muhammad and Yucer, 2009). For this reason, the countries or regional blocs sign and negotiate RTAs with diverse partners, for example, economic partnership agreement (EPA), comprehensive trade agreement (CETA), tripartite free trade agreement (TFTA), and continental free trade agreement (CFTA), which is observed in the WTO, with more than 40 agreements subscribed between 1998 and 2013 (Sorgho, 2016).

It is necessary to understand the importance of the political context in which an RTA is designed and implemented given that it determines whether the agreement will ultimately bring positive or negative effects on trade. These effects include reducing trade barriers, most favored nation liberalization and minimization of products to expand the scope of benefits through competition and trade creation (Rajapatirana, 1994). While determining a positive and negative effects of RTAs requires further empirical testing, for now it is known that trade creation for RTAs is within a range of between $1.76 \%$ and $3.80 \%$, while trade diversion as an effect of the "spaghetti bowl" is between $-0.76 \%$ and $-1.39 \%$ (Sorgho, 2016). RTAs are not only increasing but also joining together, which increases trade creation compared to diversion despite the difficulties that this "spaghetti bowl" generates worldwide.

Although many developing countries have reduced tariffs in a number of regional blocs, they remain high in the majority, increasing the risk of trade diversion (Rajapatirana, 1994). However, upon studying the effects of tariff and non-tariff barriers on trade reduction, diversion and pressure, it was found that multilateral tariffs drastically reduce trade flows, in addition to the trade diversion they generate (Haveman et al., 2003).

Even if trade flows are symmetrical, tariffs are not, and the use of asymmetrical tariffs reveals the elasticity of substitute goods (Robertson and Stevadeordal, 2009). Therefore, in the case of non-tariff barriers, it can be observed that these barriers sometimes increase the value of trade in industries with low-elasticity goods because the influence on the increase in prices outweighs the reduction in quantity (Haveman et al., 2003). However, higher tariffs in multilateral agreements divert trade towards larger exporters because the reduction in fixed costs sacrifices the exports of smaller countries (Robertson and Stevadeordal, 2009). There are two opposite effects on industries with regard to tariff and non-tariff barriers whose effects also vary depending on the nature of agreements. Although RTAs can facilitate integration in global markets, no agreement provides guarantees given that their design and implementation are determinant, in addition to the fact that implementation is compromised by the proliferation of other regional agreements (Rajapatirana, 1994).

Empirical findings suggest a significant negative relationship between the number of RTAs entered into by a country and the additional trade value attributed. Trade between the EU and the United States, for example, is perhaps the most affected by this. Instead of promoting trade, the proliferation of RTAs produces trade diversion effects, due to the higher transaction costs entailed by the massive overlapping of norms (Sorgho, 2016). If agreements have different product coverage, liberalization schedules and rules of origin, the capacity of agencies to apply the agreements will be seriously undermined. Thus, the 
ability to effectively implement agreements is a crucial question that countries should consider before signing an RTA (Rajapatirana, 1994). It is not enough to establish regional agreements for both countries and regions to become effectively integrated into international markets, much less generate trade creation in member countries, given that variations between different regional agreements and their multiplicity can generate more costs than benefits.

With respect to free trade areas, the volume of trade diversion from a non-member country to a member country during its formation may be related to the welfare of a member country or the profitability of local industries (Cheong and Wong, 2007). A large volume of trade diversion from a non-member country to a member country represents a great increase in the welfare of local industries, which makes the FTA more attractive (Krishna, 1998), something that has been contradicted by the belief that a greater volume of trade diversion implies the probability of a welfare reduction (Cheong and Wong, 2007). Free trade agreements generate trade creation and diversion effects in commodities trade; specifically, regional agreements generate greater trade diversion than bilateral agreements (Shujiro and Okabe, 2013). This difference is due to the exclusivity generated by member countries of regional agreements that must create or increase non-tariff barriers to prevent re-exportation by other member countries that have agreements or do business with non-member countries.

Bohara et al. (2004), testing the Richardson (1993) model, concluded that during the formation of an economic bloc, tariff barriers with respect to the world are very high, but they end up being reduced because the initial tariffs are created politically to protect commodities that constitute the bloc. This situation explains the high levels of trade diversion generated by economic blocs in their first years of formation. Therefore, initial tariffs on all imported goods are optimal, but at the moment at which imports from elsewhere in the world are replaced by imports from a member of the agreement, tariff collection from these industries drops significantly (Bohara et al., 2004). Robertson and Stevadeordal (2009) measured the impact of regional commodity agreements based on the gravity model with a specific focus on trade creation and diversion. ${ }^{4}$ They observed that regional agreements between developed countries tend towards trade diversion; based only on tariffs, the results suggest that trade diversion is caused by tariff barriers towards non-members. However, as the same industries that raised tariffs cease to be politically influential and their tariffs fall to an equilibrium level, the initial trade diversion is reduced or corrected through the economic pact itself (Bohara et al., 2004). For this reason, in their early years, economic integration processes tend to increase levels of trade diversion while they protect the industries that have a certain capacity for political influence.

\section{Economic integration processes and international trade}

In the majority of trade agreements -European Common Market (ECM), Canada - Ukraine Free Trade Agreement (CUFTA), NAFTA and MERCOSUR- a significant reduction in imports in some countries with regard to third parties due to RTAs is generated.It is difficult to demonstrate that these imports would not have been affected in the absence of a trade agreement; likewise, the impact of trade agreements can be significant in countries that are part of the trading bloc, and the effects of these can change over time (Magee, 2004).

\footnotetext{
${ }^{4}$ A total of 67 countries and 20 commodities are studied between 1980 and 2006 based on the commodity-specific gravity model.
} 
Oscar David Andrés Julián López Camargo \& Alexander Carvajal

The Trade Effects of Regional Agreements and Economic Integration Processes in Europe, South America, and North America

What is certain is that trade diversion does not necessarily diminish the wealth of member countries, as is generally assumed based on the perspective of the Viner model. On the contrary, with regard to customs unions, the final effect of this trade diversion can increase wealth in a country due to the net effect of two opposing tendencies resulting from the customs union (Lipsey, 1957). Thus, the customs union generated trade diversion to increase its welfare gains as long as consumers move to a higher indifference (or preference) curve (Lipsey, 1957). Although during the phases of integration in which there is high trade diversion the wealth of member countries is not reduced, it can be increased, thus making trade diversion a mean to increase wealth not only within a country, but also at the global level.

According to Magee (2008), RTAs generate a $26 \%$ increase in trade in their first four years, and trade continues to increase steadily during the first 11 years until reaching an $89 \%$ increase in trade. To illustrate this situation, let's assume trade interaction between countries A, B, and C, as described by Lipser (1957). A produces wheat and consumes clothing and is a country in which inhabitants obtain clothing through international trade. Due to its small size, there is no impact whatsoever on the prices of both goods. Although A buys clothing from C, given that it offers a lower price than B, B establishes a customs union with $\mathrm{A}$, which displaces $\mathrm{C}$ with regard to the supply of clothing and diverts trade to $\mathrm{B}$. In this case, although the customs union between $\mathrm{A}$ and $\mathrm{B}$ generates trade diversion, in the long term, it increases trading volume. Customs unions generate the greatest trade creation, doubling trade in 7 years, as occurred with the ECM; this is because free trade areas have very low trade effects in the long term, while customs unions increase trade for long periods (Magee, 2008). Thus, trade diversion is not necessarily detrimental to A, for it can improve its welfare (wealth) by obtaining profits from entering into a customs union whose only productive effect was to divert its imports from lower-cost to higher-cost producers. Additionally, the division between domestic and international prices disappears once the union is formed, because the elimination of the tariff has the effect of allowing consumers in country A to adjust their purchases to a price in proportion with how much wheat is exchanged for clothing at international prices (Lipsey, 1957). That is, through trade diversion, customs unions are able to increase the volume of wealth of member countries, compensating for the reduction in international trading volume, for if the wealth of member countries increases, international wealth increases.

However, the model by Lipsey (1957) does not take into account the impact of the substitution of goods for trade diversion or creation, for it occurs as long as there is a possibility of substitution in the customs union (Bagwhati, 1971). The absence of substitution in consumption is not a determining factor for the reduction in wealth, but in this case, a variation in production can be more significant in generating wealth than substitution in demand (Bagwhati, 1971). Additionally, in the case of customs unions, wealth as a product of trade diversion affects the balance of payments because increasing tariff barriers clearly stimulates an increase in domestic production, although its real impact on wealth is reduction (Johnson, 1974). Based on the definition of trade diversion used by Lipsey (1957) and Baghwati (1971), in which "trade diversion occurs when a country ceases to trade with a non-member country in order to trade with a member country, replacing domestic production," treats trade diversion as "a reduction in trading volume" and trade creation as "an increase in wealth volume" (Johnson, 1974). Therefore, trade diversion always reduces wealth, while trade creation always increases wealth, and the net effect of customs unions depends on the difference between trade creation and diversion (Johnson, 1974). In fact, it is observed that diversion reduces wealth in the sense that imports are fixed but not in a way that aligns with consumption (Bagwhati, 1971). There is no solid evidence to support the claim that a preferential trade 
agreement will clearly cause trade creation or that all members will benefit, but it is more likely that trade agreements that forecast global trade liberalization in all key sectors and non-restrictive rules of origin will succeed. In other words, it is not possible to increase wealth through trade diversion because wealth is reduced if the net difference tips towards diversion effects.

\section{The shift from trade diversion to trade creation on the European Union}

In the EU, during the first phase of integration (1962-1973), trade diversion is observed in which extractive industries involving raw materials and agriculture thrive, protected by high tariff and non-tariff barriers (Kokko et al., 2005). The Common Agricultural Program $(C A P)^{5}$ benefitted local producers at the expense of foreign producers that are much more efficient. However, in the second phase of integration (1974-1986), signs of trade diversion are less visible and this trend continues through the third phase of integration (1986-2000) (Kokko et al., 2005). In the case of RTAs, this has to do with the perception of possible gains if the proximity process guided by generic and agreed norms, and the differentiating characteristics of differentiating neighboring countries generate specific benefits (Bauman, 2008). It is necessary to highlight that strong economic ties with neighboring countries require participants to find common objectives and agree on the strategies needed to achieve them, which can generate trade creation (Bauman, 2008). When a country joins the EU, it tends to exhibit dynamics consistent with standard economic models of investment and adjustment costs given that it is important to highlight that tariff adjustments with regard to their increases and reductions are interpreted as shifts in trade orientation (Freund and McLaren, 1999). It is necessary to establish that the direct relationship between decreasing trade diversion is based on the development of a multilateral trade system between the economic bloc -EU- and different partners with which preferential trade agreements exist, thus encouraging global trade. As a result, levels of protectionism have fallen substantially in the EU, while duty-free products with other countries increased in the same proportion (Kokko et al., 2005). The EU registered an 18\% increase in trade between countries in the main bloc throughout the adjustment -trade orientation shift- that was consolidated over twelve years (Freund and McLaren, 1999). Regardless of trade creation or the levels of trade diversion generated during the processes of the European Single Market's formation, it can be observed that once the economic bloc was formed, it facilitated trade creation through preferential agreements with other countries or other economic blocs; thus, at the international level, the economic integration of EU countries increased global trading volume in the long term.

From the perspective of agreements seeking to liberalize regional trade, it could be said that Europe is the region with the most liberalizing agreements ${ }^{6}$ which includes a wide variety of countries with different commitments to the process of integration (Kandongan, 2005). It is observed that most trade liberalization agreements increase the wealth of all member countries, especially those in which the productive sectors had a strong component of human and labor capital, with the exception of some

\footnotetext{
5 This policy was created due to the food shortage that affected Europe and is based on supporting the prices and incomes of farmers through protectionism and assistance to cover payment defaults among domestic producers (Balthas, 2001).

${ }^{6}$ European Economic Area, the European Community's customs union, the agreements of European Free Trade Area countries, and those of the European Union countries, in particular, the Europe Agreements with Central and East European countries, the Euro-Mediterranean Agreements and the earlier Mediterranean Cooperation Agreements, as well as the Central European Free Trade Area (Kandongan, 2005).
} 
Oscar David Andrés Julián López Camargo \& Alexander Carvajal

The Trade Effects of Regional Agreements and Economic Integration Processes in Europe, South America, and North America

treaties$^{7}$ (Kandongan, 2005). In the countries that initially formed the EU, that is, the first six or "inner six", it is observed that trade was generated. They increased the sum of exports and imports, while in the agreements signed between the ECM and Iceland, Norway and Switzerland showed trade diversion for ECM non-member countries and for countries outside the treaty (Mondschein, 2011). For example, trade between the European Union and Slovakia has been increasing since 1990, and part of this increase is due to the liberalization of trade between the EU15 ${ }^{8}$ and the Central European and Eastern European Countries Integration (CEEC) through a series of tariff reductions. The effects can be said to be positive because costly national production is replaced with more affordable imports (Drabik et al., 2007). There is also a negative effect because as new member states begin to import from other member states, with the gradual elimination of tariff barriers, they are not purchasing at the most competitive prices on the market; thus, states have an incorrect allocation of resources (Drabik et al., 2007). This situation explains how, in the case of the EU, the process of economic integration increases international trading volume while the regional agreements between the ECM and other countries reduce trading volume.

The smaller and more diverse member countries of regional agreements are, the more vulnerable they are to the impacts of trade creation and diversion (Kandogan, 2005). On the other hand, as in the case of the European Economic Area (EEA), it is observed that member countries that possess similar rankings on working capital, the impact of the agreement is more sensitive to previous members, and hence, trade creation is not generated for new members joining the agreement (Kandogan, 2005). On the other hand, countries that joined the EU later generated trade diversion in their trading partners, although it must be clarified that this is also directly influenced by the size of economies and phase of integration in which they join (Cîndea and Cîndea, 2012). Trade increases by 68\% between EU member countries, and new member increase trade at the same pace as original member countries as long as they are integrated at the most advanced stage of the process (monetary union). This integration occurs due to the increase in intraregional trade (Gil et al., 2008).

In the specific case of a common currency, it has been determined that the Eurozone countries increased their trade by $0.113 \%$ over countries that did not adopt the single currency because countries with the same currency experience much more significant profits in bilateral trade than those that do not adopt the single currency (Rodney and Walsh, 2002). However, the results with regard to the EU are that, while trade between member countries increased at the time of its creation, by the 1970s, this trade creation effect diminished because as the phases of integration have advanced, their negotiations with the rest of the world have also become limited. This limitation affects the economic activities in which member countries are not as competitive and generates trade diversion effects (Bayoumi and Eichengreen, 1995). In Slovakia, a certain degree of trade creation was seen with its accession to the EU because its imports increased by $31.4 \%$ in the first accession phase, while in terms of trade diversion, this occurred due to the elimination of tariff barriers only within the EU, while protection rates were preserved for imports coming from outside the EU (Drabik et al., 2007). Thus, the probabilities of creating trade for new

\footnotetext{
${ }^{7}$ Europe Agreements and the Euro-Mediterranean Agreements, where trading partners of the European Union experienced losses, especially in labor- and resource-intensive sectors. While gains were observed in trading partners in the European Agreements, the Euro-Mediterranean agreement generated trade diversion in its member (Kandongan, 2005).

${ }^{8}$ The EU15 is a term that refers to the European Union in 1995, when it comprised the Netherlands, Belgium, Luxembourg, France, Germany, Italy, the United Kingdom, Ireland, Portugal, Spain, Austria, Greece, Denmark, Sweden and Finland.
} 
member countries in Europe depends directly on the phase of integration of which they are a part. The more advanced the phase in which they are inserted is, the greater the benefits in terms of trade creation. Meanwhile, countries that limit themselves to signing regional agreements or simply joining the Single Market will generate trade diversion in the former case and the impact on trade creation will not be significant in the latter case.

\section{The impact of the endogenous conditions on trade diversion in South America}

With regard to South America, there are two tendencies among countries seeking to form agreements to liberalize trade. On the one hand, the creation of a trading bloc in the Americas was proposed, but by 1995, the momentum had declined significantly. On the other hand, there has been a proliferation of bilateral agreements that hinder the creation of regional economic blocs (Robertson and Stevadeordal, 2009). Notable among the countries that have been part of an economic integration process is the case of Argentina. Bohara et al. (2004) based on the gravity model observed that the increase in imports from Brazil ended up reducing the capacity of local industries, and as a result, tariffs designed to protect them were reduced. In this way, MERCOSUR trading bloc reduced the tariffs established by the process of integration because intraregional trade ends up reallocating demand from the most competitive industries, and finally, it reduces the tariffs from those that disappear upon losing their role.

Among the most common justifications for economic integration in the region are increasing access to markets, generating economies of scale, strengthening the supply of regional public goods, improving competition in domestic markets, improving negotiation capacity, complementing the internal supply of basic goods, reducing bilateral imbalances in exchange rates, and improving attractiveness for potential foreign investors and others (Bauman 2008). However, in South America, there is a greater tendency towards bilateral agreements over multilateral agreements. The successful agreements of the GATT and the WTO demonstrate the benefits of multilateral agreements, while the pursuit of bilateral agreements significantly reduces the gains from multilateral agreements because evidence of trade diversion exists (Robertson and Stevadeordal, 2009). The dilemma faced by South America is that policies in this region lack a clear vision of the purpose of regional integration, negotiation processes lack clarity and the results are likely to be slow and unclear (Bauman, 2008). In the specific case of MERCOSUR's costume union, which includes $70 \%$ of the continent's surface area and $50 \%$ of its population, has had a profound impact on trade and investment in the region (Kokko et al., 2005). However, there is a proliferation of bilateral agreements in the rest of the region that have reduced multilateral liberalization given that rising tariffs increase trade diversion, making multilateral agreements less viable (Robertson and Stevadeordal, 2009). Thus, countries comprising the region are seeking economic integration though multilateral agreements. At the same time, they subscribe a large number of bilateral treaties that prevent their formation.

Regionalism in South America can be divided into two phases. The first is the "old regionalism" characterized by the import substitution industrialization (ISI) model, which in its early stages focused on incentivizing manufacturing industries while imposing high tariffs on other countries (BulmerThomas, 2001). This regionalism was focused on reinvigorating industries in countries in which domestic production was limited to the size of the local market and as a mean for promoting the modernization of production processes where economies of scale were impossible at the domestic level. However, companies maintained high production costs and were unable to export to the rest of the world (BulmerThomas, 2001). In this way, the desired results of the ISI model were never achieved, and the region even 
Oscar David Andrés Julián López Camargo \& Alexander Carvajal

The Trade Effects of Regional Agreements and Economic Integration Processes in Europe, South America, and North America

suffered economic deceleration in addition to the collapse of the majority of the industries it sought to protect.

Due to the negative impacts on economic growth, in addition to the conditions at the time when the ISI model was adopted, countries in the region decided to form regional agreements to achieve the objectives established in the ISI model. Theoretically, the nature of regional agreements and of all economic integration is to promote trade and investment among members, although the formation of RTAs has a different impact on member countries and non-member countries in terms of trade creation and diversion (Sorgho, 2016). Likewise, a "new regionalism" arose based on economic integration that was neither limited to the manufacturing sector nor sought to discriminate against extra-regional imports. Instead, the new regionalism included a wide range of new aspects to prepare Latin America for the challenges of "globalization" so that it can integrate into global trade. It should be noted that it has not escaped the weaknesses of "old regionalism," such as the signing of pacts (that are not fulfilled), nor intraregional trade that is vulnerable to external economic crises -with weak institutions and poor financing-(Bulmer-Thomas, 2001). These weaknesses are seen in the creation of the Andean Community (CAN), which had a negative impact on exports in Colombia, Ecuador and Venezuela, while no significant impact on exports was seen in Peru and Bolivia (Coulibaly, 2004).

With regard to MERCOSUR, Brazil is the only country that experienced an increase in extra-regional exports after signing the agreement, while Argentina and Uruguay saw a negative impact as a result of trade diversion and Paraguay experienced no significant impact (Coulibaly, 2004). The concrete outcome is that MERCOSUR and CAN have not achieved the expected results regarding increase in intraregional or extra-regional trade, much less in regard to preparing countries in the region for insertion into global trade.

In MERCOSUR and CAN, it has been observed that trade diversion occurred in at least one-member country in each group. In essence, there is excess demand for imports as well as little interdependence among intra-zone countries, which in the long term causes these processes to be very limited (Bauman, 1993). Despite the fact that Colombia and Venezuela experienced a period of recession from 1988 to 2000, the negative impact on the Ecuadorian economy is explained by the trade diversion generated in its exports to the CAN (Coulibaly, 2004). Regarding MERCOSUR, Argentina experienced 100\% import growth and a significant reduction in industries that previously imported very little or nothing from Brazil, which is explained by trade diversion towards Brazil after its entry into the agreement (Bohara et al. 2004). In this way, the majority of participants in the creation of the economic blocs of the regional agreements CAN and MERCOSUR were negatively affected by trade diversion (Coulibaly, 2004). Thus, in the case of South America, economic integration processes have generated more trade diversion than trade creation, while some members have been able to expand their industries at the expense of trade diversion, as in the case of Argentina and Brazil.

Part of the trade diversion in the region is due to weak intra-zone trade relationships prior to the formation of integration processes. Integration processes do not produce the expected comparative advantages, since the new products of member countries tend to consist of raw materials and light manufacturing (Bauman, 1993). This situation occurs because the economic effects of integration processes are not entirely clear (Kokko et al., 2005), especially in South America. Meanwhile, the 
differentiated trade preferences do not produce the expected results within integration processes, which prevents improvements in the competitiveness of manufactured goods in South America, with the exception of some specific sectors; consequently, products are distanced from the objective of achieving industrial transformation (Bauman, 1993). Thus, one of the main concerns is the effects of integration processes with regard to trade diversion from efficient producers, which reduces the prosperity of developing countries and has ambiguous results for member countries (Kokko et al. 2005). Integration agreements become very complex and with few favorable results for member countries in the region, unlike the results of processes such as that of the EU. This difference can be understood partly based on the EU's level of commitment in the integration phases, which explains long-term gains, while in South America, little commitment is observed in the different phases and in their progress towards integration processes.

\section{The impact of free trade on trade creation in North America}

Regarding NAFTA, it has been established that the country that has benefitted most is the United States, along with Canada, given that they possess similar conditions due to the similarity of their economic development because of the relatively high level of technology and innovation applied to their industries (Karemera and Ojah, 1998). According to the L-curve model ${ }^{9}$, it is found that the expansion in trade that has occurred since the Canada-United States FTA was signed generated trade creation (Coulombe, 2004).

However, Anderson and Wincoop (2003) through the use of a gravity model established trade diversion where the productive structures are affected by the proximity of countries. In fact, industries located on the border end up generating trade diversion in addition to the tariff effects in vertical specialization. It should be highlighted that the gravity model is based on the assumption that each economy is endowed with a fixed supply of a differentiated good where trade barriers generate diversion of international trade to domestic trade (Coulombe, 2004). Therefore, the reduction in trade barriers between Canada and the United States should increase trade between these members proportionally to a reduction in Canada's international trade (Coulombe, 2004). On the other hand, despite what is commonly assumed, Mexico, which is the only emerging economy in NAFTA, benefits by exporting raw materials such as crude oil, vegetables and other perishable goods (Karemera and Ojah, 1998). NAFTA promotes trade openness more than trade diversion because, even taking into account the fact that countries with developed economies (the United States and Canada) benefit most, developing countries such as Mexico also reap benefits, for they increase not only imports but also exports of their products.

Upon examining trade between the United States and Mexico after NAFTA, one observes a significant reduction in tariff barriers for agricultural products from Mexico to the United States, and since the treaty was signed, there was a $5.31 \%$ increase in U.S. imports from Mexico in just the first six years, maintaining $2.62 \%$ growth (Susanto et al., 2007). In addition, the United States and Canada have bilateral pacts with countries that do not belong to the treaty, these being an external factor. Overall, NAFTA generated trade creation (Karemera and Ojah, 1998), although for the United States, it could be argued that there is trade diversion due to a significant reduction in agricultural goods imported from the rest of the world. The growth of trade with Mexico increased trading volume much more than between the United States and the rest of the world, and hence, it is concluded that trade creation occurred in this sector (Susanto

\footnotetext{
${ }^{9}$ Based on a comparison of international and interprovincial trade with the GDP before and after the gradual elimination of tariff barriers between Canada and the United States to study trade diversion (Coulombe, 2004).
} 
Oscar David Andrés Julián López Camargo \& Alexander Carvajal

The Trade Effects of Regional Agreements and Economic Integration Processes in Europe, South America, and North America

et al., 2007). Therefore, trade as part of the agreement between the two developed countries generated more trade creation effects than trade diversion. Although Canada diverted trade towards the United States, its global trading volume increased. Regarding Mexico, as it is a developing country, it obtained great benefits in terms of trade, and although the United States diverted its trade towards Mexico, on agricultural matters, global trading volume increased significantly. Thus, NAFTA has created more trade than it has diverted.

\section{Conclusions}

It can be concluded that regardless of the nature of the agreements signed by countries seeking to increase their trading volume, they generate exclusion zones with regard to third parties that end up affecting global trading volume due to variations in tariffs. Additionally, both the trade creation and diversion effects are shaped by forces exogenous and endogenous to member countries than the agreements themselves. Member and non-member countries with lower economic development levels are more sensitive to trade creation or diversion effects than developed economies. Although regional agreements seek to generate trade creation effects, in the early years, they instead generate trade diversion. Over time, these agreements achieve more trade creation effects than diversion effects. However, new agreements become more interdependent with existing agreements among countries around the world, which reduces the maneuverability and impact of regional agreements that are signed. Given that the proliferation of regional agreements throughout the world and their interdependence, there is an increase in transaction costs and even the generation of trade diversion.

Free trade areas tend to establish significantly high tariff barriers, but they diminish over time because imports are diverted to the most efficient member, causing their reduction or disappear when they no longer have to protect goods that politically sought protection. Regarding customs unions, it has been observed that through trade diversion, they are able to increase volumes of wealth in countries that are part of the integration process, offsetting the reduction in international trading volume, because by increasing the wealth of member countries, global wealth is increased. It has been argued that wealth as a product of trade diversion is a result in the balance of payments because raising tariff barriers stimulates growth in domestic production, although its real impact on wealth is to diminish it. Thus, it is not possible to increase levels of wealth through trade diversion, because if the net difference tips towards diversion effects, wealth declines.

Although it can be observed that the EU presents trade diversion effects in its initial phases, the trade creation effects become more noticeable over the long term, increasing global trading volume. Regardless of the trade creation or diversion effects that occurred during the establishment of the European Single Market, it has been confirmed that once the economic bloc was created, it facilitated trade creation through preferential agreements with other countries or economic blocs. In effect, at the international level, economic integration in the EU increased global trading volume over the long term. It has been observed that the probabilities of trade creation for new member countries are directly proportional to the phase of integration of which they were part. In other words, the more advanced the phase in which they are inserted, the greater the benefits in terms of trade creation. Meanwhile, countries that are limited 
to signing regional agreements generate trade diversion, or if they simply join the Single Market, the impact on trade creation will not be significant.

Countries in South America have successively sought economic integration through multilateral agreements, but at the same time, they sign a large number of bilateral agreements that prevent the consolidation of the first agreements. The majority of regional economic integration processes have not met expectations with regard to increasing intraregional and extra-regional trade, much less with regard to preparing countries in the region for insertion into international trade. In effect, the economic integration processes have generated more trade diversion effects than creation effects; meanwhile, some members have been able to boost their industries at the expense of trade diversion. Integration processes become very complex and have few favorable results for member countries in the region, unlike the results seen in processes such as that of the EU. This difference can be explained in part by the level of commitment of the EU to the phases of integration, which demonstrates long-term gains, while in the case of South America, little commitment to the phases is demonstrated and their progress in integration processes.

Finally, on balance, NAFTA has generated more trade creation effects than diversion effects given that, upon observing trade between the United States and Mexico after the treaty was subscribed, a significant reduction is seen in tariff barriers for agricultural products exported from Mexico to the United States. Although it can be said in the case of the United States that trade diversion has occurred because a significant reduction is seen in agricultural goods imported from the rest of the world, the increase in trade with Mexico has increased trading volume much more than that between the rest of the world and the United States. Thus, it can be concluded that there has been trade creation in this sense. Additionally, trade between developed countries in NAFTA generates more trade creation effects than trade diversion because although Canada diverted its trade towards the United States, global trading volume increased through imports from the member country. Mexico, being a developing economy, obtained major benefits in terms of trade and although the United States diverted its trade towards Mexico, with regard to agriculture, global trading volume increased significantly, and therefore, the pact has created more trade than it has diverted.

\section{References}

Anderson, J. and Wincoop, E. (2003) 'Gravity with Gravitas: A solution to the Border Puzzle'. The American Economy Review online publication 20 March, doi: 10.1257/000282803321455214

Balthas, N. C. (2001) 'The common agricultural policy, past, present and future'. European Economic and Political Issues III. F. Columbus, ed. Chapter 7: 97-116. Nova Science Publishers Inc. New York 2001.

Bauman, R. (1993) 'Integración y desviación de comercio'. Revista CEPAL 51: 133-149.

Bauman, R. (2008) 'Integration in Latin American- Trends and Challenges'. Economic Commission for Latin American and the Caribbean Revista CEPAL 28(1). https://www.cepal.org/en/publications/37936-integration-latin-america-trends-and-challenges (January, 2008)

Bayoumi, T. and Eichengreen, B. (1995) 'Is regionalism simply a diversion? Evidence from the evolution of the EC and EFTA'. National Bureau of Economic Research online publication October, doi: $10.3386 /$ w5283. 
Oscar David Andrés Julián López Camargo \& Alexander Carvajal

The Trade Effects of Regional Agreements and Economic Integration Processes in Europe, South America, and North

America

Bhagwati, J. (1971) 'Trade-diverting customs unions and welfare-improvement: A clarification. The Economic Journal online publication September, doi: 10.2307/2229850.

Bhagwati, J. and Panagariya, A. (1996) 'Preferential Trading Areas and Multilateralism: Stranger Friends or Foes?'. Washington: Columbia University AEI press Discussion papers no 9596-04.

Bohara, A. K., Gewande, K. et. al. (2004) 'Trade Diversion and Declining Tariffs: Evidence from Mercosur'. Journal of International Economics 64(1), doi: 10.1016/i.jinteco.2003.07.004 (October, 2004).

Bulmer-Thomas, V. (2001) 'Regional Integration in Latin America and the Caribbean'. Bulletin of Latin American Research, 20(3). https://www.jstor.org/stable/3339734.

Cheong, J and Wong, K. (2007) 'Economic Integration, Trade Diversion and Welfare Change'. Washington: University of Washington working paper no 34/5.

Cîndea, L. and Cîndea, M. (2012) 'The euro effect on International trade'. Procedia- Social and Behavioural Sciences 58, doi: 10.1016/i.sbspro.2012.09.1109.

Coulibaly, S. (2004) 'On the assessment of trade creation and trade diversion effects of developing RTAs'. Lausanne: University Lausanne Working paper No45.

Coulombe, S. (2004) 'International Trade Diversion: The Canada-United States Agreement and The L curve'. The B.E. Journal of Economic Analysis and Policy, De Gruyter 4(1). https://ideas.repec.org/a/bpj/bejeap/vtopics.4y2004i1n16.html (July, 2004).

Drabik, D., Pockrivcak, J. et al. (2007) 'Trade Creation and Diversion in the Enlarged EU market: Evidence for agricultural Trade in Slovakia'. Czech Journal of Economics and Finance, 57 (9-10): 433-447.

Susanto, D., Rosson, P. et al. (2007) 'Trade Creation and Trade Diversion in the North American Free Trade Agreement: The Case of the Agricultural Sector. Journal of Agricultural and Applied Economics, 39(1). https://doi.org/10.1017/S1074070800022793 (28 April, 2015).

European Commission. (1996) 'Trade Creation and Trade Diversion'. The Single market review series, 4(3): 15-23.

Freund, C. and McLaren, J. (1999) 'On the Dynamics of Trade Diversion: Evidence from four Trade Blocs'. Washington: Board of Federal Reserve, International Finance Discussion Papers 637

Gil, S., Llorca, R. et al. (2008) 'Assessing the enlargement and deepening of the European Union'. The world economy, Willey Blackwell 31(9). https://ideas.repec.org/a/bla/worlde/v31y2008i9p12531272.html.

Haveman, J., Nair-Reichert, U. et al. (2003) 'How Effective Are Trade Barriers? An Empirical Analysis of Trade Reduction Diversion and Compression'. MIT press 85(2), https://doi.org/10.1162/rest.2003.85.2.480.

Haveman, J., Nair-Reichert, U. et al. (1998) 'Trade Reduction, Diversion and Compression: Empirical regularities in the effects of protective measures. West Lafayette: Purdue University Discussion Papers 98-007.

Johnson, H. (1974) 'Trade-Diverting Customs Unions: A Comment'. Economic Journal 84(335) online publication September doi:10.2307/2231045.

Kandongan, Y. (2005) 'Trade Creation and Diversion Effects of Europe's regional liberalization agreements. Michigan: William Davidson Institute working paper number 746.

Karemera, D. and Ojah, K. (1998) 'An industrial Analysis of Trade creation and diversion effects of NAFTA'. Journal of Economic Integration, 13(3). https://www.jstor.org/stable/23000519.

Krishna, P. (1998) 'Regionalism and Multilateralism: A political Economy approach'. The quarterly journal of economics 113(1): 227-251.

Kokko, A., Matä, T. et al. (2005) 'European Integration and Trade diversion'. SIEPS Swedish institute for European studies 7: 6-59

Lipsey, R. (1957) 'The Theory of Customs Unions: Trade diversion and welfare'. Economic New Series 24(93): 40-46.

Magee, C. (2004) 'Trade Creation, Trade Diversion, and Endogenous regionalism'. Econometric Society 2004 North American Summer Meetings 289. https://ideas.repec.org/p/ecm/nasm04/289.html. 
Magee, C. (2008). 'New measures of trade creation and trade diversion'. Journal of International Economics 75(2), doi: 10.1016/i.jinteco.2008.03.006.

Mildner, S. and Schmucker, C. (2013) 'Trade Agreement with Side Effects?' Stifnung Wissenschaft und Politik. German Institute for international and security affairs. SPW 18. https://www.files.ethz.ch/isn/166748/2013C18_mdn_schmucker.pdf .

Mondschein, L. (2011). 'The European Union and regional trade agreements: Helping or Hurting the Inner six'. Bachelor Thesis. Pittsburgh: Division of economics. http://www.antolindavies.com/thesis/mondschein.pdf.

Muhammad, K. and Yucer, A. (2009) 'Impact of regional trade agreements: Trade Creation and Trade diversion in western Hemisphere'. International Journal of Economic Issues 3(2). https://basepub.dauphine.fr/handle/123456789/10626.

Pandey, S. (2006) 'Spaghetti Bowl Phenomenon and Crucifixion of Multilateralism: Task ahead for WTO'. Press University Jodhpur 10. doi:10.2139/ssrn.951392

Prehn, S., Brümmer, B. et al. (2012) 'An extended Viner Model: Trade creation, diversion and reduction'. DARE Diskussionsbeitrag 1212: 5-18.

Rajapatirana, S. (1994) 'The evolution of trade treaties and trade creation: lessons for Latin America". Policy, Research working paper; no. WPS 1371. Washington, DC: World Bank. http://documents.worldbank.org/curated/en/880061468753259901/The-evolution-of-tradetreaties-and-trade-creation-lessons-for-Latin-America

Richardson, M., 1993. Endogenous protection and trade diversion. Journal of International Economics $34(3-4), 309-324$.

Robertson, R. and Stevadeordal, A. (2009) 'Gravity, Bilateral Agreements and Trade Diversion in the Americas'. Cuadernos de Economia vol 46(133). doi: 10.4067/S0717-68212009000100001.

Rodney, T. and Walsh, B. (2002). 'The Effect of a Common Currency on Trade: Ireland Before and After the Sterling link'. European Economic Review (46): 1125-2351.

Saryan, S. (1998) 'Could Regional Economic Cooperation generate trade creation and trade diversion effects without altering Trade policies of members? Preliminary Results from a Gravity application to BSEC'. Bilkent University, Department of Economics Discussion Paper no 98-10.

Sorgho, Z. (2016) 'RTAs Proliferation and Trade Diversion effects: Evidence of the Spaghetti Bowl Phenomenon'. The World Economy, 39(2). doi: 10.1111/twec.12295.

Shujiro, U. and Okabe, M. (2013) 'Trade Creation and Diversion effects of regional trade agreements: A product-level analysis'. The World Economy 37(2). doi: 10.1111/twec.12099.

Viner, J. (1950) The Custom Union Issue. New York: Carnegie Endowment for international Peace.

Yeats, A., Amjadi, A. et al. (1997). 'Did Domestic Policies Marginalize Africa in International Trade?' Washington: World Bank document 16313.

(c) (i) () Cor International License, which permits the use, adaption and sharing as long as you give appropriate credit to the original author(s) and the source. The images or other third party material in this article are included in the article's Creative Commons license, unless indicated otherwise in a credit line to the material. If materials are not included in the article's Creative Commons license and your intended use is not permitted by statutory regulation or exceeds the permitted use, you will need to obtain permission directly from the copyright holder.

To view a copy of this license, visit http://creativecommons.org/licenses/by-nc/4.0/.

(C) The Author(s) 2020. 